\title{
Religion or Ruse? African Jamaican Spiritual Practices and Police Deception in Canada
}

\author{
Danielle N. Boaz
}

\begin{abstract}
African-derived spiritual beliefs described as 'Obeah' have played a significant role in policing the illegal activities of Jamaicans in Ontario, where the majority of Caribbean immigrants in Canada have settled. Posing as spiritual advisors, police agents and undercover officers have convinced suspected criminals to divulge the details of their offenses as a component of rituals purportedly designed to protect the suspects against the spirits of their victims and guard against detection by the authorities. Canadian courts have consistently upheld the legality of these deceptions, finding that Obeah rituals fall outside the standards of protected spiritual interactions or confessions. These cases reveal the limitations of the recognition of African diaspora religions in Canada, and demonstrate that, in response to media allegations that Jamaican immigrants disproportionately commit violent crime, persons of Caribbean descent attempt to secure their acceptance in the global north by delegitimizing African derived faiths.
\end{abstract}

Keywords: Obeah, Caribbean, Diaspora, Jamaica, Religious Freedom

\section{Introduction}

In the mid twentieth century, a variety of factors led Caribbean persons to increasingly migrate to North America, forming immigrant communities in major cities like Miami, New York, and Toronto. In the latter part of the twentieth century, as these communities became larger and more established, North American authorities and media outlets accused Caribbean immigrants 


\section{Danielle N. Boaz}

of becoming the chief perpetrators of violent crime in these cities. In response, some immigrants sought to preserve their own reputation and space in their host lands by identifying the supposed culprits as a particular sect of their community - newer arrivals who were adherents of African diaspora religions. In their attempts to salvage their community's image, these immigrants provided the courts with the rhetoric and, one could argue, the permission, to refuse to provide legal protection to African diaspora religions.

Scholarship on the relationship between Obeah and the law has increased in recent years, with at least two books (Handler \& Bilby 2012; Paton 2015) and multiple articles exploring the colonial prohibition and prosecution of Obeah, as well as the rationale for and legitimacy of its continued proscription (i.e. Paton 2009; Boaz 2017). Two recent works have discussed the Canadian cases that are at the centre of this article, exploring the idea that adherents have deployed Obeah for harmful, criminal purposes (Crosson 2015), and that expert witnesses were instrumental in classifying the practices at issue as extra-legal (Clarke 2017). This article will expand upon these works by examining the background to the litigation and, using theories introduced in Aisha Khan's Dark Arts and Diaspora (2017), arguing that these cases are the product of persons of Caribbean descent attempting to secure their acceptance in the global north by delegitimizing African derived faiths.

In Dark Arts and Diaspora, Khan (2017) briefly references one of the recent Canadian cases denying Obeah the same legal protections granted to other faiths, noting that a police officer at the centre of the case was described as a man with Caribbean ancestry. Khan uses this case as an introductory remark to explain that 'communities are, through consensus, moral arbiters' who determine what is a 'legitimate religion' (Khan 2017:42). If Khan had unpacked these Canadian cases further, I argue, the central role of the Caribbean community in commencing these cases would have become even more apparent. I also contend that when one examines the work that other scholars have conducted on another important case involving Afro-Caribbean religion in the United States, the Church of the Lukumi Babalu Aye v. City of Hialeah, it becomes clear that these Obeah controversies are part of a larger trend.

Citing the City of Hialeah case and comparing it to recent Obeah cases, I argue that legal controversies surrounding Afro-Caribbean religions in the global north followed particular patterns and originated from certain segments of immigrant communities. First, I contend that these cases arose in moments 
when Cuban and Jamaican populations found themselves stereotyped as the primary perpetrators of violent crime in their host countries. Persons from those communities then undertook measures to attempt to display a multifaceted immigrant population - with more established persons differentiating themselves from the new arrivals. In both cases, these measures involved denigrating the African-diasporic religions of their homeland, describing them as witchcraft and sorcery, and linking practitioners with violent crime. Courts often (at least initially) adopted these arguments, finding that while African diaspora faiths may be religions, their central practices are nevertheless secular. To reach this conclusion, the courts contrasted African diaspora religious beliefs and Abrahamic faiths.

\section{Miami Cubans and the Santeria Case}

In 1986, a group of Santeria practitioners incorporated a religious organization, the Church of the Lukumi Babalu Aye, and the following year announced their plans to open a permanent place of worship and an educational institution in Hialeah, Florida, a residential city in Miami-Dade County known for Cuban immigrant settlement (Palmie 1996). The Church was the first of its kind - a legally recognized organization that planned to bring the practice of this African Cuban religion, which had predominantly been observed discretely in private residences, into the public sphere. In response to the Church's impending opening, the City Council of Hialeah passed a series of ordinances that prohibited the practice of animal sacrifice, a necessary component of Santeria, in an effort to effectively proscribe the religion itself. The Church of the Lukumi challenged the validity of these statutes but district and circuit courts in Florida upheld the laws. However, in 1993, this litigation made its way to the United States Supreme Court, which issued a landmark ruling determining that Santeria was a religion entitled to the same protections as other faiths. These proceedings share some important characteristics with the cases about African diaspora spirituality that would commence in Canada in the subsequent two decades.

First and foremost, the Church of the Lukumi case was born of cleavages within the Cuban community. Cuban presence in the United States was minimal before the mid twentieth century. Immigration dramatically increased in 1959 after Fidel Castro and Che Guevara won the revolution that 


\section{Danielle N. Boaz}

turned Cuba into a communist country and dispossessed wealthier, white citizens who had thrived under the previous president, Fulgencio Batista, and his pro-United States system of capitalism and racial segregation. Hundreds of thousands of Cubans fled the island, many of whom emigrated to the United States (Perez 2004). They settled in major cities such as New York and Miami.

The controversy surrounding African diaspora religion arose from Cubans' concerns about how their host society perceived them. In the first two decades of Cuban immigration, these primarily white, pro-capitalist arrivals enjoyed political, social and economic mobility in North America. Popular perceptions of Cubans began to shift by the 1980s, however, with the arrival of more racially and economically diverse immigrants (Palmie 1996). No longer wealthy former-business owners fleeing after the seizure of their property and destruction of their way of life, Cuban immigrants of the 1980s became stereotyped by the Mariel boatlift which, among its hundreds of thousands of 'refugees,' is believed to have brought immigrants released from Cuba's prisons to the shores of South Florida (O'Brien 2004). Fighting against the typecast of a crime-ridden, drug-trafficking immigration population, Cubans in South Florida seized upon the rejection of an African diasporic religion, Santeria, as one mechanism to salvage their diminishing reputation. They depicted practitioners of this 'black' religion as barbaric and dangerous, alleging that they distributed drugs and spread AIDS in the midst of their animal sacrifices (Palmie 1996). Scholars have argued that the response of the Cuban community in Hialeah and the Cuban-led City Council represented an effort of earlier migrants from the 1950s and 1960s to protect their reputation as 'good and white' immigrants, against the influx of darker skinned Cubans and rising crime in South Florida communities (Palmie 1996).

The second important aspect of these cases that parallel recent Canadian controversies is that these more established immigrants grounded their arguments in the idea that African diaspora belief systems were not real religions, and denigrated or dismissed the aspects of these religions that are different from Abrahamic faiths. For example, when the Hialeah City Council first met regarding the Church of the Lukumi's proposed plans to open in Hialeah, Herman Echevarria, the council president, asked 'What can we do to prevent the church from opening?' (O'Brien 2004:44). Immediately turning to their method of animal sacrifice as a distinctive characteristic of Santeria, city council member Andrew Mejides explained that 'The Bible says we are 
allowed to sacrifice an animal for consumption, but not for any other purpose. I don't believe the Bible allows that (Santeria methods of slaughter)' (O'Brien 2004:42). The City Council then passed a series of ordinances that, without mentioning Santeria directly, were so closely tailored to target this African Cuban faith that no other animal slaughters would be proscribed. In particular, they carefully carved out exceptions for recognized religions, such Jewish kosher and Islamic halaal slaughters, by only prohibiting the killing of an animal in a 'private ritual or ceremony not for the primary purpose of food consumption' (O'Brien 2004: 45, 163-168).

The third element that would be repeated in Canadian cases was that the residents of Hialeah, the City Council, and even the District Court, justified the infringements on the Church of the Lukumi's religious freedom by describing Santeria as more comparable to 'voodooism', devil worship, or witchcraft than to mainstream religions. In the City Council's first meeting about the opening of the Church, when the leader of the Church, Ernesto Pichardo, addressed the room, residents referred to him as 'Satan', and 'the anti-Christ'. The chaplain of the Hialeah police department further proclaimed that Santeria practitioners worship demons (O'Brien 2004:43; Palmie 1996:187-188). When the Church of the Lukumi's appeal reached the U.S. Supreme Court, the City Council adopted this language, arguing that animal sacrifice was legitimately proscribed because it was not just a practice employed by Santeria adherents but was also utilized in the performance of 'malevolent magic' and was 'engaged in by Satanists, by witchcraft, voodoo' - belief systems not previously recognized as guaranteed religious freedoms (O’Brien 2004:128).

The fourth significant element of this controversy is that there are undertones of the City Council and Hialeah residents' denunciations of Santeria found in the District Court's ruling approving the legislation barring animal sacrifice. For example, the District Court stressed that Santeria was not a religion of the entire population of Cuba; rather, it was an 'underground religion practiced mostly by slaves and the descendants of slaves' that eventually 'spilled over from the black population to the white population' (District Court 1989:1478). The Court also noted that historically, 'Santeria was seen as backward' (District Court 1989:1478). Perhaps most explicitly, the Court asserted that 'the practice was not, and is not today, socially accepted by the majority of the Cuban population' (District Court 1989:1478). Despite these allusions to the divisive nature of the practice of Santeria in South 


\section{Danielle N. Boaz}

Florida, the District Court found in favour of the government, averring that there was no intent to discriminate against Santeria itself; the only issue was a particular practice - animal sacrifice - which the City intended to prevent no matter 'whatever individual, religion or cult it was practiced by' (District Court 1989:1479).

The final aspect of these cases that would be repeated in Canadian decisions is that the yardstick by which the litigants measured Santeria was to examine how comparable it was to Abrahamic religions. There are many examples of the City's efforts to draw distinctions between Santeria and Abrahamic faiths that could be cited, but some of the clearest come from the City's arguments when the case reached the Supreme Court. In the City's brief to the Supreme Court, they argued that Santeria/Lucumi sacrifices were more 'inhumane', 'indifferent', and 'unreliable' than those in Kosher slaughter (Respondent's Brief 1992:58-59). They also simply contended that the practice of animal sacrifice was 'non-religious'. The City averred, 'The evidence at trial, however, established and district court found that animal "sacrifices" also occur in secular "ritual[s] or ceremonies" [citation omitted], which are not constitutionally protected. Petitioners did not even attempt to argue that the ordinances would be unconstitutional if applied to sacrifices of animals for nonreligious purposes' (Respondent's Brief 1992:58-59).

Rather than arguing that all religions should be afforded equal protection regardless of their social acceptability or similarity to mainstream faiths, the Church of the Lukumi Babalu Aye emphasized that their beliefs were more closely related to Abrahamic beliefs and practices than the City had represented. In their brief to the Supreme Court, the Church contended that 'Animal sacrifice is one of the oldest and most widespread religious practices,' which 'remains important in modern Islam', and 'was central to Jewish scriptures and to Jewish ritual practice' (Petitioner's Brief 1992: 30-31). Further they argued that the practice was only eradicated from Christianity because 'they believe that Christ's sacrifice on the cross is good for all time and all people' (Petitioner's Brief 1992:30-31). Ultimately, the Supreme Court seems to have reached a decision that animal sacrifice in Santeria is analogous to ritual slaughter in mainstream religions. The Court accepted that animal sacrifice has 'ancient roots' in Abrahamic faiths, as it is 'mentioned throughout the Old Testament', and is present in modern-day Islam (Church of the Lukumi v. City of Hialeah 1993:524-525). The Court asserted that 'given the historical association between religion and animal sacrifice, [citation omitted] 
petitioners' assertion that animal sacrifice is an integral part of their religion cannot be deemed bizarre or incredible' (Church of the Lukumi v. City of Hialeah 1993:531).

The City of Hialeah case would later become famous because of the ultimate success of Santeria practitioners in securing a decision in favour of their freedom exercise rights. After six years of litigation, the Supreme Court of the United States struck down the Hialeah ordinances, recognizing that the City Council had impermissibly intended to ban the practice of Santeria (Church of Lukumi Babalu Aye v. City of Hialeah 1993) Although this case stands out because of its result, the passage of this legislation against animal sacrifice in Cuban-dominated Hialeah, the divisions between older and newer generations of Cuban immigrants, the demonization of religions of the African diaspora and the comparisons with Abrahamic religion, are all patterns that would be repeated in later litigation in Ontario.

\section{Jamaican Canadians and the Obeah Cases in Canada}

This section will now turn to the Obeah cases recently heard by the Court of Appeals of Ontario and examine how the origins of these controversies repeat the pattern of internal policing in immigrant communities that commenced the City of Hialeah case in the United States.

\section{Obeah and its Historical Proscription}

Obeah is a vague, broad term encompassing a variety of, primarily Africanderived, spiritual practices in the former British Caribbean. It is difficult to define because specific beliefs and ritual practices might vary greatly from island to island; however, this belief system is generally characterized by individualized relationships between Obeah practitioners and their clients. Caribbean persons consult and compensate Obeah practitioners for performing a wide range of services related to bodily health (healing or inducing physical ailments), financial wellbeing (finding employment, increasing the success of one's business, or getting money that was lost or is owed), family relationships (finding or keeping a lover), and the legal system (evading arrest or winning a court case) as well as conjuring and expelling spirits. Obeah rituals are 


\section{Danielle N. Boaz}

typically conducted through the manipulation of supernatural and natural forces, rather than by appealing to a god or pantheon of deities. Practitioners can, and historically did, perform malevolent, individualistic rites as well as benevolent, community-oriented rituals (Olmos \& Gebert 2003; Murrell 2010).

The legal history of Obeah long precedes its arrival in Canada, dating back more than 250 years in the British Caribbean. It was first banned in Jamaica in 1760, after so-called Obeah practitioners administered ritual oaths of allegiance and distributed protective charms to participants in a major slave uprising known as Tacky's rebellion. Before emancipation in the 1830s, colonial authorities proscribed Obeah in many other parts of the Caribbean as well, claiming that spiritual rituals were used to terrorize enslaved Africans, forcing them to participate in insurrections and causing them to die from wasting illnesses when they believed themselves the target of harmful rituals (Paton 2015).

After the abolition of slavery, legislators broadened their description of Obeah practices and the statutes that proscribed them from the focus on Obeah's use in insurrections and destructive rituals to a general assertion that individuals who professed to have supernatural powers were charlatans and vagrants. In the late nineteenth and early twentieth centuries, these laws were enforced frequently against individuals who performed divination and medicoreligious healing, or provided rituals to generate good luck in matters of love, employment, and legal proceedings for their clients. The practice of Obeah remains illegal in most former British colonies in the Caribbean, including Jamaica (Handler \& Bilby 2012; Paton 2015).

Recent developments suggest slowly changing attitudes toward Obeah in the Caribbean. Since the 1970s, four countries have decriminalized Obeah, including Trinidad and Tobago whose parliament determined in 2000 that these colonial laws infringed on the religious freedom of practitioners of African diaspora faiths (Handler \& Bilby 2012, Parliament of Trinidad and Tobago 2000). While other Caribbean nations retain these laws on the books, they have generally ceased to enforce them (Paton 2015:279). Yet this long history of proscription of Obeah has had a delegitimizing effect on African derived spiritual practices and the bias against Obeah appears to have become embedded in the minds of Jamaicans as they travel to the global north. Obeah has become a mechanism for internally policing the criminal activities of other Jamaicans in Toronto, where approximately three-fourths of Caribbean immigrants in Canada reside (Jones 2010:81). 


\section{Background to the Canadian Obeah Cases}

In January of 1999, Jamaican-born cousins Marlin Rowe and Dwayne Lawes, alongside Dain Campbell and 'Brownman' robbed a Toronto-Dominion Bank. During the process of the robbery, Rowe shot and killed a bank teller named Nancy Kidd (Mitchell \& Mascoll 2001). Rowe and his accomplices were apprehended after another Caribbean immigrant, Rhyll Carty, pretended to be their spiritual advisor then reported their confidential communications to the police (Queen v. Rowe 2006).

In 1998, Rowe and Lawes solicited the assistance of Carty in circumventing arrest and prosecution for their planned criminal activities. Carty was a self-described 'spiritualist' and 'psychic counsellor', who had a reputation in the Toronto Jamaican community as an Obeah practitioner (Queen v. Rowe 2006:4). He owned a shop in Toronto called O'Shanti's Herbal Store, advertised as a location that provided counselling services, as well as sold religious articles, candles, and herbs. Carty's primary source of income came from 'performing 'psychic' or 'spiritual' readings for clients from the Caribbean community' (Queen v. Rowe 2006:3). Rowe and Lawes became aware of Carty's reputation as an Obeah practitioner through Rowe's friend, Jacqueline Thompson, and Rowe's aunt, Sonia Gallimore, both of whom were Carty's regular clients. The latter introduced Rowe and Lawes to Carty, and they quickly inquired about his services. They told Carty that they were bank robbers and promised to pay him a substantial sum of money if he could help them evade the authorities.

Over the following weeks, Rowe and Lawes met with Carty twice, first at his shop and then at Gallimore's home. They detailed their plans for the robbery as well as renewed their requests for spiritual protection for their illegal activities. Whether Carty provided them with any 'protection' services at this time is unclear; but he reportedly admonished Rowe and Lawes not to do anything 'crazy or stupid', and threatened to turn them in to the police if anyone got hurt as a result of their crimes (Queen v. Rowe 2006:4).

On January $11^{\text {th }} 1999$, Rowe, Lawes, and their accomplices carried out their plan to rob a Toronto bank. Within 48 hours, Carty learned of the robbery, and reported his knowledge about the crime to the police. In exchange for payment as a police agent and a $\$ 200,000$ reward, Carty agreed to help the authorities in their investigation. He allowed the police to set up equipment to record his phone conversations and the activities in his shop, and he contacted 


\section{Danielle N. Boaz}

Rowe and arranged a meeting to discuss how he could help them. Lawes and Brownman had already fled to Jamaica ${ }^{1}$, but Carty convinced Rowe and Campbell that he could assist them in evading the authorities.

Carty instructed Rowe and Campbell to each place an egg inside a black sock, knot it twice, and bring the socks with them to Carty's shop later that evening. When they arrived, Carty, who had donned a bulletproof vest under priestly robes, explained that in order to 'protect' them, Rowe and Campbell would have to divulge all the details of their participation in the crime. Rowe described the guns they had used in the robbery, and confessed that he, not realizing the safety of his weapon was off, had accidentally shot the bank teller, Nancy Kidd. Additionally, Rowe described the stolen minivan that they had used as a getaway car and informed Carty where they had stashed it. He and Campbell also paid Carty a fee of 3,000 dollars for his spiritual services, taken out of the proceeds of the robbery (Queen v. Rowe 2006, Mitchell 2000).

After Carty helped the police build a case against his 'clients,' they were arrested and charged with bank robbery. Carty was called as a witness for the prosecution, and he testified about what Rowe and Campbell had admitted to him during the Obeah rituals. As the police had collected little other evidence against the defendants, Carty's testimony was a central part of the prosecution's case (Queen v. Rowe 2006:13). Rowe was particularly aggrieved by Carty's subterfuge because, prior to his admission to Carty, the police had not known who had shot the bank teller. On the basis of this confession, Rowe was also charged with first-degree murder.

Rowe raised numerous challenges to Carty's evidence against him at trial, arguing that the statements he made to Carty were inadmissible for two interrelated reasons. First and foremost, Rowe claimed that his communications with Carty were part of a religious exchange that should be protected by the special privilege that safeguards confidential communications with spiritual advisors. If not shielded by religious privilege, then Rowe argued that Carty's ruse constituted a 'dirty trick' - that it transgressed the boundaries of permissible deceptions that the police and their agents may employ in solving a crime. The trial and appellate courts found against Rowe on both challenges,

${ }^{1}$ Lawes was finally apprehended approximately two years after the robbery but it does not appear that 'Brownman' was ever conclusively identified or charged with the robbery. 
determining that the defendants' interactions with Carty represented 'a corrupt criminal relationship, not a legitimate relationship between a religious practitioner and a penitent' (Queen v. Rowe 2006:10). Ultimately, and based largely on the introduction of Carty's evidence, Rowe was found guilty of first degree murder and both men were convicted of robbery.

While the Rowe case was making its way through the appellate courts, a Toronto police department decided to employ similar tactics in a murder investigation. In 2003 and 2004, a series of homicides occurred and the police suspected that Jamaican Canadians were involved. These murders began in December of 2003, when a man named Adrian Baptiste was found dead in Youhan Oraha's car (Queen v. Welsh 2013). Several months later, Shemaul Cunningham was killed, and police suspected that Oraha had committed the murder in retaliation against those who had shot Baptiste. When Oraha himself was gunned down by multiple assailants about one month after Cunningham's death, police believed that the individuals who murdered Oraha were part of this cycle of violence. They suspected that two Jamaican Canadian brothers, Evol Robinson and Jahmar Welsh, were involved because Cunningham had been the latter's best friend.

Lacking sufficient evidence to prosecute anyone for Oraha's murder, a Jamaican Canadian police officer named Andrew Cooper employed an elaborate scheme to obtain Robinson's and Welsh's confessions. He posed as an Obeah practitioner and befriended their mother, Colette Robinson, after the authorities learned that she believed in spirits and thought the ghost of Cunningham was still around her. Going by the name 'Leon,' Cooper convinced Ms. Robinson that she and her sons were being haunted by an evil spirit (Oraha), who was in conflict with a good spirit (Cunningham). Cooper insisted that he could protect them, but only if they confessed what they had done to anger the malevolent ghost. To this purported end, he met with Ms. Robinson over the course of four months, and had ten meetings with her son Evol and two with Welsh's friend, Reuben Pinnock. All of these sessions were secretly taped, as were all of Cooper's phone calls with Ms. Robinson and the suspects, to be presented as evidence against them at trial (Queen v. Welsh 2013:10).

From their first meeting, Cooper's interactions with Ms. Robinson, Evol Robinson, and Pinnock were infused with detailed deceptions meant to convince the suspects of his powers and thus encourage the disclosure of their involvement in Oraha's murder. Cooper initiated his relationship with Ms. 


\section{Danielle N. Boaz}

Robinson by staging an accident between his car and hers. When he introduced himself, he claimed he felt a 'vibe' from her and offered to pay for the damage to her vehicle. Several meetings followed the accident, and Cooper warned Ms. Robinson that a vengeful spirit surrounded her and this spirit was capable of manipulating police officers and judges (Queen v. Welsh 2013:14-16).

After Cooper began performing ritual services for Ms. Robinson, he had his fellow officers place a dead crow on Ms. Robinson's doorstep. Cooper told her that the crow died because of the protection spell he had performed for her. Later, Cooper asked another police officer to pull Ms. Robinson over for a traffic stop. To illustrate the purported power of a handkerchief he had provided to keep her out of trouble with the police, Cooper arranged for this officer to pretend to become ill when he approached her and release Ms. Robinson without citation. (Queen v. Welsh 2013:14-16).

Once he finally convinced Ms. Robinson and the suspects of his powers, Cooper persuaded Evol Robinson and Pinnock to take him to the scene of the crime, claiming that in order to protect them from the evil spirit, he needed to go where it was created. They took him to where Oraha was murdered and confessed to being present at the time of his death but insisted that was the extent of their involvement. Frustrated by the limited confessions, Cooper had Ms. Robinson arrested, and convinced her son, Evol, that her detention was brought about by Oraha's spirit. Cooper insisted that the spirit was escalating, and that Evol needed to be more forthcoming about what he had done to anger it so that Cooper could protect him from being arrested as well. Under this pressure, Evol admitted his involvement in Oraha's death, and also implicated his brother Welsh and several other accomplices.

Soon thereafter, Welsh, Robinson, and Pinnock were arrested and charged with first-degree murder. At trial, Robinson and Pinnock raised similar arguments about the inadmissibility of the statements they made to Cooper as Rowe had made about his interactions with Carty. They contended that they had viewed Cooper as a religious adviser or sacred specialist, analogous to a priest or imam; therefore, their statements to him should be protected by common law privilege and his deception violated their charter rights to freedom of religion. They further asserted that Cooper's actions constituted obtaining evidence through a 'dirty trick.' The Court of Appeals for Ontario once again determined that the Obeah exchanges were not protected by religious privilege and that the police interest in catching criminals outweighed any harm caused by their deception. 


\section{Internal Policing in Canadian Obeah Cases}

Unlike the former British West Indies, where persons of European heritage imposed restrictions on Obeah practices, in Canada, persons of Caribbean descent developed and implemented the ruses that employed spiritual rituals from their homelands to help uncover criminals in their midst. Exploiting the bonds that often exist in immigrant communities, they used language and customs from the Caribbean to solicit Jamaican Canadians to engage rituals where they were forced to divulge their illegal activities. To justify their deceptions, the architects of these plans undermined the legitimacy of this African derived belief system, describing Obeah to the authorities as sorcery, witchcraft, or charlatanism.

The first evidence that these controversies were the result of internal policing in Jamaican Obeah communities is that, similarly to the Santeria controversy in Florida, these cases began at a time when there was widespread public debates about whether Jamaicans, who were the largest population of Caribbean immigrants in Canada, were frequent perpetrators of violent crimes (Government of Canada 2006). In 1994, Jamaican immigrants were convicted of two high profile murders - the first of a white Canadian woman who was shot in an ice cream parlour, and the second of a police constable killed in an apartment complex. The following year, partially in response to these murders, Canadian legislators passed a federal statute that facilitated the deportation of immigrants who had been convicted of a crime that was punishable by at least ten years' imprisonment (Tyler 1998). Three years later, in 1998, Julian Falconer and Carmen Ellis released a report on the application of the law, asserting that Jamaicans were by far the largest immigrant group removed from the country for serious crimes. They argued that, as Jamaicans formed the basis for passing the statute and comprised an astounding 138 of the 355 individuals who had been deported from Ontario since the law went into effect, authorities discriminated in its application. Their claims that police and immigration authorities discriminated against Jamaicans may actually have had negative repercussions for public perceptions of Jamaicans because they resurrected conversations about the 1994 murders, and encouraged speculation about whether Jamaicans were more prone to commit violent crime than the rest of the population.

Rowe and his associates committed the bank robbery less than six months after the release of the Falconer-Ellis report. Furthermore, the death of 


\section{Danielle N. Boaz}

Nancy Kidd during this crime marked the first time in twenty years that someone had been murdered during a bank robbery in Canada (Mitchell \& Mascoll 2001). One cannot separate Carty's decision to go to elaborate lengths to help the police apprehend his 'clients' from the impact that this robbery would have had on public perceptions of Caribbean immigrants in Canada.

One can see a similar pattern of public discourse about the prevalence of crime in Caribbean, particularly Jamaican, communities in Canada before the police developed the Obeah ruse in the Welsh case. These discussions reached their height in 2002 after the Toronto Star, the largest newspaper in Canada, featured a series of articles asserting that black people in Toronto were the victims of the police's racial profiling (i.e. 'Black Crime Rates Highest'). The Citizen's Centre for Freedom and Democracy responded by publishing a multi-author report asserting that 'blacks were simply involved in more such (violent) crime', and that this was true 'particularly among immigrants from Jamaica' (Stock 2002:50). Although Jamaican Canadians comprised less than $2.4 \%$ of the population of Toronto, the authors claimed that they committed $9.5 \%$ of violent crimes in the city. Quoting a Toronto criminal lawyer who explained that 'Canada has inherited Jamaica's crime problem', the authors contested the continued immigration of individuals from the island, reminding the public that Canada 'is not required to continue the importation of large numbers from one of the most violent and corrupt countries on earth' (Grace 2002:38). Again, one should consider that this resurgence of discussions about the relationship between Jamaican immigrants and violent crime may have been one of the catalysts for a police officer of Caribbean heritage to deploy an elaborate scheme to identify the persons involved in the series of murders that plagued immigrant communities.

Secondly, like Cuban opposition to Santeria in South Florida, these Obeah cases appear to have been the products of older, more established generations of Jamaican Canadians protecting the reputation of their community against younger and, in some cases, more recent arrivals. All of the known bank robbers, Campbell, Lawes, and Rowe, were in their twenties, and the latter were described as individuals who had been born in Jamaica but were living in Canada 'for several years' (Mitchell \& Mascoll 1999:np). Few details were disclosed about convicted murderers Welsh, Pinnock, and Robinson, though all were described as being of Jamaican heritage and in their early twenties (Powell 2008).

In contrast to the accused criminals, the Obeah practitioners were older 
and appear to have had more experience in the global north. Officer Cooper, who posed as the Obeah practitioner 'Leon' in the Welsh case, was a secondgeneration immigrant. He was born to a South African father and Jamaican mother in Britain before moving to Canada, where he had worked as a police officer for 18 years prior to the Welsh case (Humphreys 2008). Although Carty's ethnic background was never explicitly described in the Rowe proceedings or in newspaper reports about this trial, evidence suggests that he was likely of Caribbean descent. Furthermore, like Cooper, Carty appears to have been an older and a more established immigrant than the defendants.

Carty was known to own a thriving business that had been in operation for some time, and he portrayed himself as unfamiliar with actual Obeah rituals, suggesting that he was not a recent arrival and many not have been Jamaican born. However, he described his main business as providing spiritual readings for Caribbean persons residing in Toronto and he styled his supposedly manufactured rituals on Jamaican Obeah practices. Carty also named his business 'O'Shanti's Herbal Store,' likely a shortened version of 'Ashanti,' an African ethnic group who had substantial cultural impact in Jamaica.

In each of these cases, the older, more established immigrants went to great lengths to exploit their common heritage with the defendants, pushing them to become more involved in spiritual practices than they would have been without the traps. First, they gained access to the defendants through a family member who was both a believer in the power of these African-derived rituals and a client of the Obeah practitioner. Rowe and Lawes met Carty through the former's aunt. Even though Rowe and Lawes had solicited Carty's help prior to the bank robbery, they were not his regular clients and had no history of hiring him for other spiritual services. Instead, their practitioner-client relationship with Carty began in earnest after the bank robbery, and was commenced by Carty for the sole basis of obtaining their confessions.

While their attempts to hire Carty before the robbery suggest that Rowe and Lawes likely believed in his powers, Robinson and Pinnock appear to have been manipulated and coerced into employing Cooper. After learning that Robinson's mother was a long-time Obeah adherent and thought herself haunted by Cunningham's ghost, Cooper employed the plan to ensnare the suspects through their mother. To gain her trust, he spoke to her (as well as the suspects) in Jamaican Creole, and approached her using familiar Jamaican 


\section{Danielle N. Boaz}

terminology, referencing the justice system as 'Babylon' and the police as 'the beast' or 'beastman' (Queen v. Welsh 2013:9). Cooper repeatedly engaged Ms. Robinson in purported rituals from her homeland, trusting that she had instilled her children with a belief in evil spirits and would impress upon her sons and their accomplices the efficacy of African Jamaican spiritual practices in eradicating them ${ }^{2}$.

After manipulating the defendants into confessing by convincing them of the efficacy of Obeah rituals, police officers and agents then undermined these African derived spiritual practices by explaining to the courts that they were not religious. These tactics, once again, resemble the Santeria case when the Cuban-dominated City Council and residents of Hialeah contended that the faith at issue was more akin to 'witchcraft' than recognized religion. For example, although Carty had been operating as a self-described 'spiritualist' and had been profiting off of his reputation as an Obeah practitioner, he denigrated his own practice as a non-religious ruse. According to the appellate court, Carty 'conceded that he had no genuine spiritual powers and that he could be described as a 'con man and a charlatan' because he misled his clients into believing otherwise' (Queen v. Rowe 2006:4).

The police used similar language when they laid out their plan to have Cooper pose as an Obeah practitioner to gain more evidence against Welsh and Robinson. Detective Sergeant Jarvis, who had worked on the Rowe case and, based on this experience, had constructed the Obeah ruse used in Welsh, explained 'that he thought that Obeah was not a religion but a form of witchcraft or voodoo and that he would not use a similar operation for an established religion' (Queen v. Welsh 2013:31). Cooper, the JamaicanCanadian police officer who carried out Jarvis's scheme, also indicated that he regarded Obeah as a type of 'voodoo and witchcraft' (Queen v. Pinnock 2007: 9). Even in official police records, the officers noted that the Merriam-Webster dictionary definition of Obeah was 'the use of sorcery and magic ritual' in the Caribbean and described their plan stating 'the undercover officer will explore

${ }^{2}$ Ironically, the Court of Appeals for Ontario ruled that the fact that they had not previously engaged in Obeah rituals before encountering 'Leon' greatly diminished the impact that this ruse had on their religious freedom. The Court both questioned the sincerity of their religious beliefs and distinguished this from a scenario where an individual had a pre-existing spiritual relationship with religious official who became a police informant. 
the named person's willingness to use sorcery to fight the police and the judiciary' (Queen v. Welsh 2013:14, e.a.).

These cases therefore share three parallels with the City of Hialeah case that demonstrate that all these disputes were the result of Caribbean immigrants denigrating religions from their homeland to attempt to repair their reputation in the global north. First, all three cases originated during a time period when these immigrant populations were accused of perpetrating violent crime in their host communities. Second, the initial challenges to these religions clearly arose from the immigrants themselves and were led by older, more established immigrants and lodged against younger, new generations. Third, the tactics espoused in these cases were very similar - the individuals opposing these faiths argued that they were 'witchcraft,' 'voodoo,' or something less than religion. As the next section will discuss, although these strategies to denounce Santeria ultimately failed before the U.S. Supreme Court in the City of Hialeah case, they have thus far been successful in Canadian Obeah cases.

\section{Religious Freedom and Obeah in Canada}

It is important to recall that when the District Court found in favour of the City of Hialeah's attempts to ban animal sacrifice and the practice of Santeria, the Court noted that Santeria was an African-derived faith that was not socially acceptable amongst the majority of the Cuban population and stressed that it differed from Abrahamic faiths. When read together, the trial and appellate court rulings in Rowe and Welsh reveal similar considerations about the social acceptability of Obeah as a religion and, once again, Abrahamic faiths were the yardstick for determining what was covered by legal guarantees of religious freedom. Due to the distinct structure and function of the Obeah rituals at issue in these cases, the courts determined that these practices were essentially secular and not entitled to the constitutional and statutory protections that shield religious actors from excessive governmental intrusions.

Rowe appears to have been the first case in which Canadian courts were ever asked to determine whether the Afro-Caribbean spiritual practices known as 'Obeah' satisfied the legal definition of 'religion'. Likely because of the novelty of the consideration of Obeah as a religion, the defence hired a Catholic priest, Father Thomas Lynch, as well as two professors of religious studies, Dr. Abrahim Khan and Dr. Frederick Case, to testify to the religious 


\section{Danielle N. Boaz}

nature of the Obeah sessions. However, on cross-examination, the prosecution pushed the experts and Father Lynch to admit several significant distinctions between the Obeah rites at issue in the case and the practices of Abrahamic religions, including: the offering of protection from arrest, charging a fee for spiritual services (particularly one collected from the proceeds of a crime) and the absence of repentance. Because of these distinctions, the trial judge determined and the Court of Appeals agreed that while Obeah might be a recognized religion, these specific exchanges were not 'religious.' As such, the defendants' sessions with Carty were not confidential religious exchanges.

Unlike Rowe, where the rulings centred on the inconsistencies in the experts' arguments that Obeah was comparable to recognized religions, the trial judge in Welsh analysed the defendants' exchanges with Cooper under a four-prong test used to determine whether religious communications are protected by privilege. However, the essence of issue remained the samewhether these exchanges satisfied the definition of religious exchanges according to Abrahamic values and whether the religious practices were socially acceptable. The first two elements of the test pertained to the confidentiality of the exchanges; the third was that the relationship is one 'which in the opinion of the community ought to be sedulously fostered', and fourth was that the injury to the relationship from disclosing the communications must be greater than the benefit derived from 'the correct disposal of litigation' (Queen v. Welsh 2013:20). While the trial judge did not dispute the centrality of confidentiality between an Obeah practitioner and his client, he found that it failed the third prong of the test because their purpose in consulting 'Leon' (Cooper) was to 'obstruct law enforcement officials and the judiciary from prosecuting them' and the judge believed there was no community interest in allowing them to avoid penalties for their crimes' (Queen v. Welsh 2013:20-21). This same reasoning also led the judge to find that the fourth prong was not satisfied; he believed that the harm in excluding the evidence and letting the defendants go free was greater than any damage to the relationship between Obeah practitioners and their clients (Queen v. Welsh 2013:21). Therefore in Welsh, as in Rowe, the determination that Obeah rituals were not privileged religious exchanges hinged on the fact that, unlike practitioners of Abrahamic religions, the defendants had not consulted a spiritual advisor to cleanse them of their 'sins,' but rather to avoid the legal consequences of their actions. In each case, the court ruled that these communications were not 'religious' or were not the type of spiritual 
interactions that were intended for protection when the concept of religious privilege was established.

The courts' determinations that police agents and officers posing as Obeah practitioners was a valid method of obtaining evidence followed the same line of reasoning. The analysis was based on Rothman, a 1981 case in which the Supreme Court of Canada determined that police were entitled to use some deceit to further their investigations but that evidence obtained through 'dirty tricks' was not admissible at trial. The justices had explained that 'conduct on their part that shocks the community', would render a police tactic a 'dirty trick' (Rothman v. The Queen 1981: 642). They provided a series of examples of such 'shocking' behaviour, including ' $(t)$ hat a police officer pretend to be a lock-up chaplain and hear a suspect's confession' (Rothman v. The Queen 1981: 697). The defendants in Rowe and Welsh argued that employing a police officer or agent to pretend to perform Obeah rituals on their behalf was analogous to pretending to be a chaplain to take a suspect's confession, and thus constituted a 'dirty trick.'

In both cases, the Court of Appeals for Ontario disagreed. The judges determined that while these situations shared some superficial similarities to the example cited in Rothman, the defendants' purpose in consulting an Obeah practitioner rendered an otherwise religious exchange secular. The Court of Appeals explained that the Rothman example 'presumes the sincerity of the religious belief of the penitent' who intends 'the use of the confessional as a means of helping people overcome their errors by forgiving their sins' (Queen v. Rowe 2006:14). As with the question of the applicability of religious privilege, the ruling hinged on the fact that the Court viewed consulting a spiritual advisor to get away with a crime or rid oneself of an evil spirit as a secular activity that was significantly different from confessing one's 'sins' to seek absolution from god.

Perhaps the most telling part of these decisions is that in addition to finding that Obeah exchanges were not legally protected because they were distinct from mainstream religious communications, the Court of Appeals also emphasized that their determination that police could pretend to be an Obeah practitioner had no bearing on other circumstances where an officer posed as a religious adviser. The judges indicated that these Obeah ruses were the only cases of this kind they were aware of and that 'the police must proceed with the utmost caution' when dealing with religious freedom (Queen v. Welsh 2013:39). They explained that the Welsh ruling does not mean 'that the police 


\section{Danielle N. Boaz}

are entitled to pose as religious advisers and expect that statements obtained from religiously-motivated suspects will be admitted' (Queen v. Welsh 2013:39). They clarified that '(i)n cases where suspects have sincere religious beliefs and seek counselling from a supposed religious adviser for non-corrupt religious reasons, the result could well be different' (Queen v. Welsh 2013: 30).

As this rhetoric demonstrates, the courts' decisions in Rowe and Welsh reveal a very limited protection of African diasporic religions. The judges assumed that a religion must be centred on a belief in a dichotomy between good and evil, as well as grounded on the idea that a faithful adherent would only use religion for ethical purposes such as confession and absolution. Obeah, on the other hand, is based on the African-derived premise that supernatural forces and beings, as well as the priests or adepts who interact with them, are neither exclusively good nor evil and can be appealed to for any desired end (Murrell 2010). One of the most common functions of Obeah practitioners is to assist their clients with their legal woes, including preventing arrest and impeding prosecution (Olmos \& Gebert 2003). Thus, in ruling that some of the most central Obeah rituals were not protected by religious privilege or shielded from police intervention, the Court of Appeals carved out a very narrow definition of 'religion,' and left practitioners of this African diaspora faith more vulnerable to state infringements on their rights than adherents of other belief systems.

\section{Conclusion}

As scholars examine the experiences of Caribbean immigrants in North America, it is important to note that litigation over the practice of African diaspora religions has dramatically increased in the United States and Canada since the late twentieth century. In addition to the cases discussed herein, adherents of Rastafari, Palo, Vodou and Santeria have faced numerous challenges to their religious freedom in recent years. ${ }^{3}$ As this article has discussed, these controversies are not just the response of Western

\footnotetext{
${ }^{3}$ Rastafari practitioners have been prosecuted for illegal use of marijuana, Palo practitioners have been charged with grave robbing and child endangerment, Vodou practitioners have also been charged with grave robbing and Santeria practitioners continue to contend with restrictions on their animal sacrifices.
} 
governments to unfamiliar faiths, they are also partially grounded in the desire of migrant communities themselves seeking to improve their reputation by sacrificing their spiritual heritage. They are part and parcel of disputes between newer and more established immigrants as well as between younger and older generations, and occur in moments when immigrant communities are being portrayed as the perpetrators of violent crime. These cases both cause and represent spiritual and racial cleavages within Caribbean migrant communities in the global north, and undoubtedly have a chilling impact on African diaspora religious freedom in North America.

\section{References}

Boaz, D. 2017. Obeah, Vagrancy, and the Boundaries of Religious Freedom: Analyzing the Proscription of 'Pretending to Possess Supernatural Powers' in the Anglophone Caribbean. Journal of Law and Religion 32,3: $423-448$.

https://doi.org/10.1017/jlr.2017.44

Clark, K. 2017. Beyond Genealogies: Expertise and Religious Knowledge in Legal Cases Involving African Diasporic Publics. Transforming Anthropology 25,2: 130 - 155.

https://doi.org/10.1111/traa.12101

Crosson, J. 2015. What Obeah Does Do: Healing, Harm, and the Limits of

Religion. Journal of Africana Religions 3,2: 151 - 176.

https://doi.org/10.5325/jafrireli.3.2.0151

Falconer, J. N. \& C. Ellis 1998. Colour Profiling: The Ultimate 'Just- desserts'.

Paper presented at the American Bar Association Meeting, Toronto, Ontario.

Government of Cananda 2006. Immigrant Population by Place of Birth and

Period of Immigration. Available at: http://www.statcan.gc.ca/tablestableaux/sum-som/101/cst01/demo24a-eng.htm

(Accessed on 20 December 2018.)

Grace, K. 2002. Did they Fall from the Sky? Citizens Centre Report, December 2.

Handler, J. \& K. Bilby 2012. Enacting Power: The Criminalization of Obeah in the Anglophone Caribbean, 1760 - 2011. Kingston: University of the West Indies Press. 
https://www.amazon.com/Enacting-Power-Criminalization-AnglophoneCaribbean/dp/9766403155

Jones, T. 2010. Race, Place and Social Mobility of Jamaicans in Toronto. In

Frazier, J., J. Darden \& N. Henry (eds.): The African Diaspora in the

United States and Canada at the Dawn of the $21^{\text {st }}$ Century. Albany: State University of New York Press.

Khan, A. 2008. Dark Arts and Disapora. Diaspora 17,1: 40 - 63.

https://doi.org/10.1353/dsp.2008.0013

Murrell N. 2010. Afro-Caribbean Religions: An Introduction to their Historical, Cultural, and Sacred Traditions. Philadelphia: Temple University Press.

https://www.amazon.com/Afro-Caribbean-Religions-Introduction-

Historical-Traditions/dp/1439900418

O'Brien, D. 2004. Animal Sacrifice and Religious Freedom: Church of the Lukumi Babalu Aye v. City of Hialeah. Lawrence, Kansas: University Press of Kansas.

https://www.amazon.com/Animal-Sacrifice-Religious-FreedomHialeah/dp/070061303X

Olmos M. \& L. Parvasini-Gebert 2003. Creole Religions of the Caribbean: An Introduction from Vodou and Santeria to Obeah and Espiritismo. New York: New York University Press.

https://www.amazon.com/Creole-Religions-Caribbean-IntroductionEspiritismo/dp/0814727204

Palmie, S. 1996. Which Center, Whose Margin? Notes towards an Archaeology of U.S. Supreme Court Case 91-948, 1993. In Harris, O. (ed.): Inside and Outside the Law. London: Routledge.

Parliament of Trinidad and Tobago. 2000. An Act to Amend certain Provisions of the Summary Courts Act, the Summary Offences Act and the Offences Against the Person Act to Remove Certain Discriminatory Religious References of 2000. Trinidad and Tobago Gazette 39, 224: S1117 - 1122. Available at: http://www.ttparliament.org/legislations/a2000-85.pdf (Accessed on 20 December 2018.)

Paton, D. 2009. Obeah Acts: Producing and Policing the Boundaries of Religion in the Caribbean. Small Axe 28,2009: 1 - 18. https://doi.org/10.1215/07990537-2008-002

Paton, D. 2015. The Cultural Politics of Obeah: Religion, Colonialism and Modernity in the Caribbean World. Cambridge: CUP. 
https://doi.org/10.1017/CBO9781139198417

Perez, A. 2004. Wet Foot, Dry Foot: The Recurring Controversy between Cubans, Haitians, and the United States Immigration Policy. Nova Law Review 28,2: 437 - 465.

Stock, P. 2002. Too Many Black Criminals. Citizens Centre Report. December 2.

\section{Court Cases}

Church of the Lukumi Babalu Aye v. City of Hialeah. 1989. 723 F. Supp. 1467.

Church of Lukumi Babalu Aye v. City of Hialeah. 1993. 508 U.S. 520.

Petitioner's Brief, Church of the Lukumi Babalu Aye, Inc. v. City of Hialeah, 1992 U.S. S. Ct. Briefs LEXIS 535 (May 22, 1992).

Respondent's Brief, Church of the Lukumi Babalu Aye, Inc. v. City of Hialeah,

1992 U.S. S. Ct. Briefs LEXIS 534 (July 31, 1992).

Rothman v. The Queen. 1981. 1 SCR 640.

The Queen v. Marlon Rowe. 2006. CanLII 14235 (ON CA).

The Queen v. Welsh. 2013. ONCA 190 (CanLII).

The Queen v. Ruben Pinnock. 2007. CanLII 13943 (ON SC).

\section{Media Articles}

Humphreys, A. 2008. Masquerade Sting Raises Concerns. National Post March 1.

Mitchell, B. 2000. Con Man's Psychic in Line to Receive \$200,000 Reward: Got Crucial Information from Defendant in Nancy Kidd Murder Trial. Toronto Star December 27.

Mitchell, B. \& P. Mascol 2001. Dramatic Arrest in Jamaica Nabs Bank Slaying Suspect: T-D Employee Shot to Death during 1999 Brampton Robbery. Toronto Star February 23.

Mitchell, B. \& P. Mascol 1999. Third Suspect Sought in Fatal Bank Robbery. Toronto Star January 20.

Powell, B. 2008. Jurors Warned to Avoid Lure of 'CSI Effect'; Legal Community Concerned Phenomenon is Influencing Juries in Canada, Police Say. Toronto Star March 10. 
Danielle N. Boaz

Tyler, T. 1998. Deportation Law 'targets' Jamaicans. Toronto Star August 19. No Author. 2002. Black Crime Rates Highest: No One was Born Violent .... What's Causing these Problems? Toronto Star October 26.

Danielle N. Boaz Assistant Professor Africana Studies University of North Carolina at Charlotte dboaz@uncc.edu 